\title{
GNEN-1: a spontaneously immortalized cell line from gastric neuroendocrine neoplasia
}

\author{
Klaus W Fagerstedt ${ }^{1}$, , Tom Böhling ${ }^{1,2}$, Harri Sihto ${ }^{1}$, Tarja Salonen², Fang Zhao', Mia Kero ${ }^{1,2}$, Leif C Andersson ${ }^{1}$ and \\ Johanna Arola ${ }^{1,2}$ \\ 'Department of Pathology, University of Helsinki, Helsinki, Finland \\ ${ }^{2}$ HUH Diagnostic Center and Helsinki University Hospital, Helsinki, Finland
}

Correspondence should be addressed to K W Fagerstedt: klaus.wj.fagerstedt@helsinki.fi

\begin{abstract}
Mixed neuroendocrine-non-neuroendocrine neoplasms (MINEN) are rare tumors that consist of at least $30 \%$ of both neuroendocrine and non-neuroendocrine components. The MINEN data concerning the pathogenesis of MINEN suggest a monoclonal origin. We describe a spontaneously immortalized cell line derived from gastric MINEN called GNEN-1. Primary tumor consisted of components of high-grade neuroendocrine carcinoma and adenocarcinoma. The GNEN-1 cell line was initiated from metastatic tumor cells of peritoneal fluid and expresses a purely neuroendocrine phenotype. The GNEN-1 cell line grows as monolayers and has retained the neuroendocrine phenotype with positivity for chromogranin A in immunohistochemistry. Electron microscopy showed cytoplasmic dense core granules and axon hillocks. The karyotype revealed alterations typical of both adenocarcinoma and neuroendocrine carcinoma such as trisomy 7 and 8. GNEN-1 cells were also positive for stanniocalcin-1, a marker of poor prognosis in gastric carcinomas. Expression of several markers related to neuroendocrine tumors was found. There have been only a few studies on the pathogenesis of MINEN and management of the disease due to the rarity of this tumor type. Here we describe for the first time an immortalized cell line derived from mixed gastric NEN. The GNEN-1 line offers a tool for future research on gastric NEN.
\end{abstract} Key Words - STC1

\section{Introduction}

Mixed neuroendocrine-non-neuroendocrine neoplasm (MINEN) is a rare tumor that was reclassified in the latest WHO Classification of Tumours of the Digestive system (1). MINEN was originally described in 1924 (2). According to the definition, MINEN is a composite neoplasm containing both neuroendocrine and non-neuroendocrine (e.g. adenocarcinoma or squamous cell carcinoma) components. It was called MANEC in the 2010 Blue Book edition of Gastrointestinal Tract (GI) tumors, as most of the non-neuroendocrine components in GI tract are adenocarcinomas. By definition, a MINEN tumor should consist of two histologically and immunohistochemically discrete components, each of which constitutes at least
$30 \%$ of the tumor volume. Gastric MINENs can appear anywhere in the stomach, but most are found in the cardiac or antral region (1). There are also case reports of this mixed tumor in the urinary tract and nasal cavity (3, 4). Specific etiological factors for MINENs are unknown. Merkel cell polyomavirus (MCPyV) has been detected in rare cases of gastric NEC (1).

The incidence of MINENs is unknown. Gastric tumors represent $20 \%$ of the mixed tumors in the digestive system, including the pancreatobiliary system (5). While the median overall survival of mixed tumors of the appendix has been reported to be 6.5 years (6), no reliable survival data are available since appendiceal goblet cell

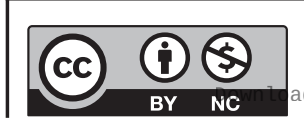


tumors are no longer considered MINENs (2). No specific epidemiological data exist (7). Previous studies on MINEN tumors are mostly case reports with immunohistochemical and genetic studies of the tumor tissue. The pathogenesis of the MINEN tumor has been discussed, but most findings support the hypothesis that the exocrine and endocrine portions of the tumor are derived from the bidirectional differentiation of a common stem cell $(8,9,10,11)$.

Stanniocalcin 1 (STC1) is a 56-kD homodimeric protein with autocrine and paracrine functions that protect cells from hypoxia and oxidative stress (12). Expression of STC1 has been shown to be a negative prognostic factor for gastric cancer (13). The role of STC1 in NE tumors is unknown. Other recently reported markers for neuroendocrine tumors include regenerating family member 4 (REG4), atonal BHLH transcription factor 1 (ATOH1 or MATH1), and antizyme inhibitor 2 (AZIN2) $(14,15)$. REG4 has been reported to inhibit apoptosis, but the molecular details remain unknown (15).

The insulinoma-associated 1 (INSM1) gene encodes a protein with five zinc-finger domains and is an important regulator of beta-cell development in the pancreas. INSM1 has also been shown to have specificity and sensitivity in neuroendocrine lung tumors $(16,17)$. The ISL LIM homebox 1 (ISL1) gene encodes a protein that binds to the insulin gene enhancer region and may regulate the insulin gene expression. ISL1 is also associated with neuroendocrine carcinoma of the lung and neuroendocrine cancer of the GI tract $(18,19)$.

Tumor cell lines offer versatile tools for studying the molecular biology of neoplasms. Here we describe the establishment and characterization of a spontaneously transformed cell line from a gastric MINEN, composed of high-grade neuroendocrine carcinoma and adenocarcinoma components. To the best of our knowledge, there are no previous reported cell lines derived from gastric MINEN.

\section{Materials and methods}

\section{Patient clinical history}

A middle-aged person underwent a preoperative control for surgical cholecystectomy. Ultrasound imaging revealed an incidental finding of multiple liver metastases. No primary tumor was visualized in a full-body CT scan. Gastroscopy revealed an approximately $1-\mathrm{cm}$ diameter mass with necrotic center at the border between the corpus and antrum. Biopsies were taken from the liver metastases and from the gastric tumor. Six rounds of chemotherapy (etoposide and cisplatin) were administered with a good initial response. However, disease progression was observed after 3 months. A trial with temodal-xeloda was a failure. The patient developed ascites with malignant cells and died 6 months after the initial findings of liver metastasis.

\section{Primary tumor and metastasis}

The gastric tumor revealed the following two morphological components: an adenocarcinoma of the intestinal subtype (Fig. 1C and D) and a high-grade neuroendocrine carcinoma (NEC) (Fig. 1A and B). Only the NEC component was found in the biopsies from the liver metastases (Fig. 1E and F). The immunohistochemical profiles of two components in the primary tumor and the liver metastasis are shown in Table 1. CGH on DNA from the primary gastric tumor showed amplifications in the areas 5p14.3-p12, 6q22.1qter, 8q22.2-q24.1, and the whole 17q arm in CGH. The main deletions were $16 \mathrm{q}$ and $17 \mathrm{p}$ whole arms and almost the entire chromosome 19.

\section{Establishment of a cell line}

Fresh ascites fluid containing malignant cells collected from disease progression was mixed with an equal volume of RPMI-1640 culture medium (Sigma-Aldrich) supplemented with $10 \%(\mathrm{~V} / \mathrm{V})$ fetal bovine serum (FBS) (Gibco and Thermo-Fisher) and 1\% (V/V) antibiotics (penicillin 10,000 IU/mL and streptomycin $10 \mathrm{mg} / \mathrm{mL}$ ) (Sigma-Aldrich) and placed on $\varnothing 10 \mathrm{~cm}$ cell culture dishes (Eppendorf AG 22331, Hamburg, Germany). Ascites was also centrifuged to pellet cells and the supernatant recovered and filtered through a $22-\mu \mathrm{m}$ filter to obtain cellfree fluid that was added as a supplement to early passages of the cultures. The cells were cultured at $37^{\circ} \mathrm{C}$ in a humidified atmosphere with $5 \% \mathrm{CO}_{2}$ in air. After 2 weeks of culturing, colonies of adherent polygonic cells accumulated growing in RPMI-1640 medium with 10\% FBS without addition of ascites fluid. Cell cultures reaching approximately $80 \%$ confluence were detached by treatment with trypsinversene (Lonza) for subculturing. The studies were started at passage 12 and ended at passage 36 . The established cell line was named GNEN-1.

\section{Growth dynamics of the cell line}

The cells were passaged and grown in $5 \times 3$ wells of a 96-well plate. The cells were counted in three wells a day for 5 days.

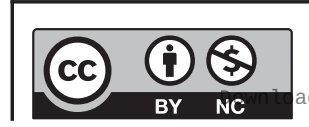

This work is licensed under a Creative Commons Attribution-NonCommercial 4.0 International License. ded from Bioscientifica.com at 04/26/2023 09:05:56AM 

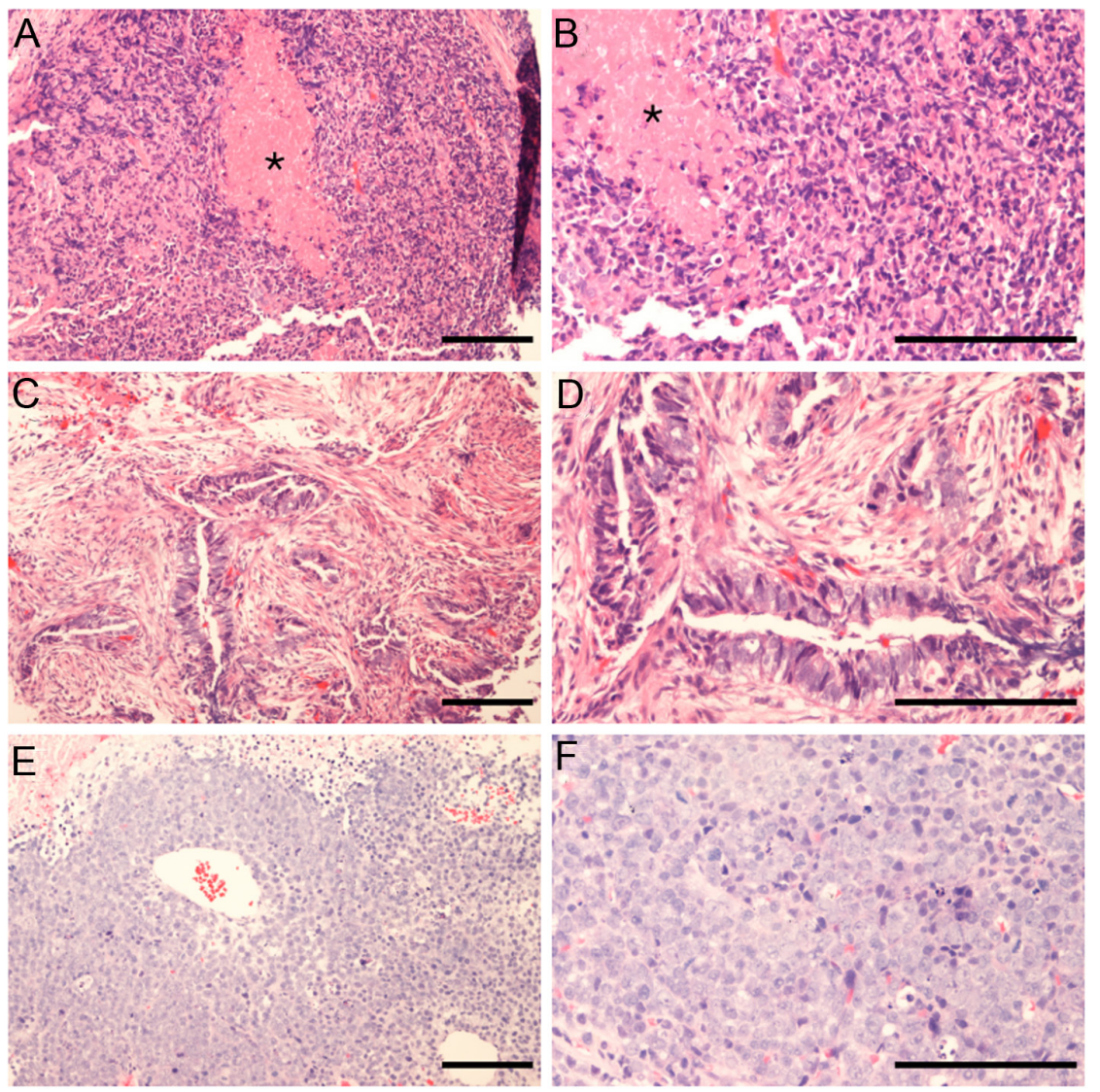

\section{Figure 1}

H\&E staining of the primary tumor and the metastasis. The neuroendocrine carcinoma (NEC) component of the primary tumor $(A) \times 10,(B) \times 20$. Some necrosis is seen between the tumor cells (asterisk). The adenocarcinoma (A, C) component of the primary tumor $(C) \times 10,(D) \times 20$. The ductal structures are visible. (E) The NEC component of the liver metastasis $(E) \times 10,(F) \times 20$. All the scale bars represent $200 \mu \mathrm{m}$.
An average was calculated from the triplets each day. The results are presented in the graph in Fig. 2.

\section{GNEN-1 cells growth in semi-solid matrix, Matrige ${ }^{\circledR}$}

GNEN-1 cells were first grown into spheroids; the spheroids were picked with a pipette and the cultured in semisolid matrix, Matrigel ${ }^{\circ}$ according to the manufacturer's instructions (Discovery Labware Inc., Bedford, MA, USA).

\section{Histological and IHC stainings of the cell line}

The paraffin blocks of the GNEN-1 cells (p.16) were cut and stained with Mayer's hematoxylin and eosin (H\&E) and AbPAS.

The GNEN-1 cells were cultivated on Lab-Tek ${ }^{\circ} \mathrm{II}$ Chamber slides with one well according to the manufacturer's instructions. The passages used in the staining are given after the primary antibody in brackets.

The IHC staining of the GNEN-1 cell line was performed in two different ways, using manual technique and a fully automated staining instrument. The slides were fixed with $3.5 \%$ paraformaldehyde (PFA) in PBS. Permeabilization was performed with NP40. The primary antibodies, presented in Table 2, s (AZIN2 (p.16), REG IV (p.16), STC 1 (p.19), chromogranin A (p.16), MATH 1 (p.16), CD56 (p.18), and synaptophysin (p.18)) were diluted in DAKO REAL ${ }^{\circ}$ antibody diluent (S2022, Dako/Agilent) and incubated overnight in $+4^{\circ} \mathrm{C}$. Secondary antibody (Vectastain Elite ABC kit, Sec-IgG: anti-rabbit goat-Ig and anti-mouse Horse-Ig) was diluted in normal serum and PBS and incubated for $30 \mathrm{~min}$ in room temperature. The Avidin-biotin complex was made and used according to the manufacturer's instructions (Vector Laboratories, Vectastain Elite $\mathrm{ABC}$ kit, REF: PK-6102). Staining was

Table 1 Immunohistochemistry of the primary tumors, both components and the metastasis.

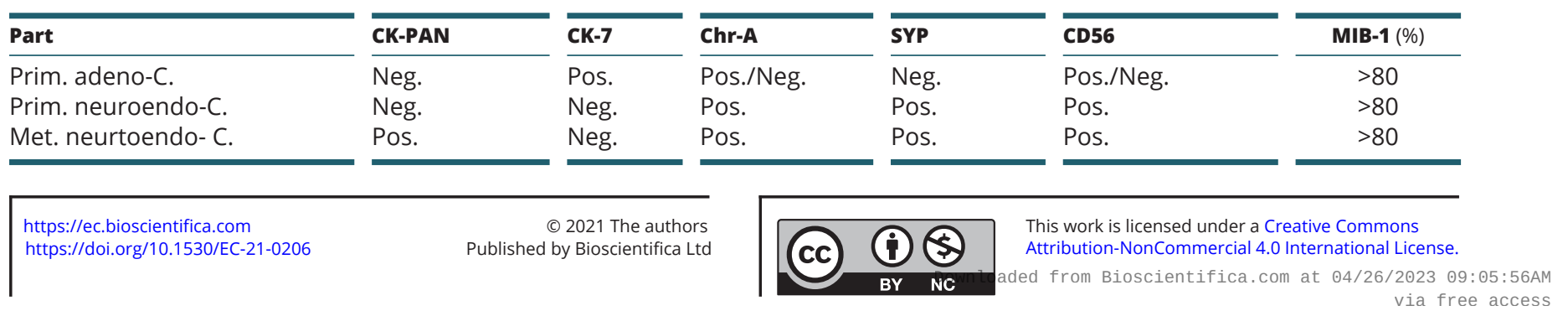



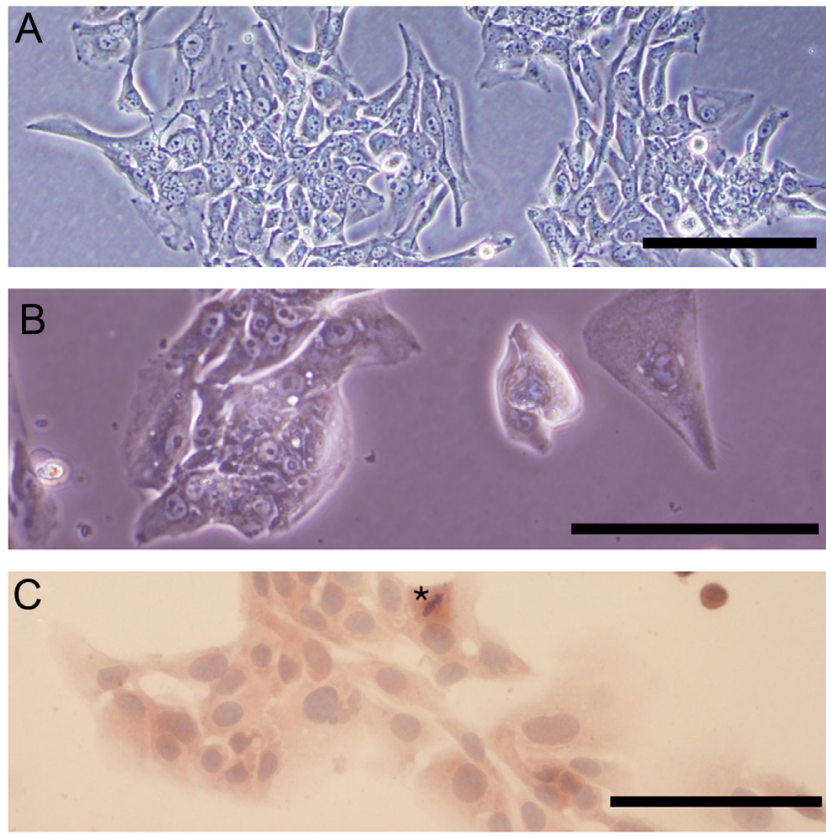

\section{Figure 2}

(A and B) Native GNEN-1 cells on the growth surface. The cells grow in clusters adherent to each other and the growth surface. The cells have dendritic-like sprouts from the soma. Clear nucleoli are seen. (C) GNEN-1 cells stained immunohistochemically with chromogranin A. Clear granular cytoplasmic staining can be seen as well as one mitotic figure (asterisk). All the scale bars represent $100 \mu \mathrm{m}$.

revealed with an aminoethyle-carbazole (AEC) and $\mathrm{H}_{2} \mathrm{O}_{2}$ solution in $0.05 \mathrm{M}$ sodium-acetate solution ( $\mathrm{pH}$ 5).

A Ventana Benchmark Ultra instrument (Roche) was utilized for the INSM1 (p.21) and ISL1 (p.21) antibodies (Table 2). For these antibodies, pretreatment was performed using cell conditioning 1 buffer, pH8.5, 20 min at $98^{\circ} \mathrm{C}$. The incubation time for INSM1 was 48 min at $36^{\circ} \mathrm{C}$ and for ISL1, $32 \mathrm{~min}$ at $36^{\circ} \mathrm{C}$. The multimer- based detection kits were used to detect and visualize the antibodies. UltraView Universal DAB Detection Kit (760-500, Roche) for ISL1 and OptiView DAB IHC Detection Kit (760-700, Roche) for INSM1. Separate amplification step was added to the protocol for ISL1 by using the amplification kit (760-099, Roche).

Finally, the slides were counterstained with Mayer's hematoxylin (S3309, Dako) and mounted.

Negative controls were made for the manual stainings on GNEN-1 cells, according to the same procedure as mentioned above, except the primary antibody was excluded. Positive controls were made for the automized stainings (ISL1 and INSM1) according to the procedure above. Normal pancreas tissue was used for the positive controls.

\section{Imaging}

All images taken of the HE, Ab-PAS, and IHC slides were taken with Nikon Digital sight DS-Fi2 trough a Nikon Eclipse 80i microscope.

\section{TEM}

GNEN-1 cells were fixed with pre-warmed 2.5\% (V/V) glutaraldehyde in culture medium at $37^{\circ} \mathrm{C}$ for $15 \mathrm{~min}$, scraped off the plates, and pelleted by centrifugation. The pellets were further fixed in $2.5 \%$ glutaraldehyde for $1 \mathrm{~h}$. The fixed sample was post-fixed by $1 \%$ osmium tetroxide, dehydrated in graded ethanol, and embedded in Epoxy LX-112 resin. Sections of 60-80 nm thickness were cut and were observed under a JEOL JEM1400 (Tokyo, Japan) at 80 kV. Digital electron micrographs were taken by a Morada TEM digital camera (EMSIS GmbH, Muenster, Germany).

Table 2 Antibodies used in the immunohistochemical stainings done on the GNEN-1 cells.

\begin{tabular}{|c|c|c|c|}
\hline Antibody & Clone & Dilution & Manufacturer \\
\hline AZIN2 & K3 & $1: 400$ & Raised by us (34) \\
\hline REG IV & $\begin{array}{l}\text { Mouse } \\
\text { monoclonal }\end{array}$ & $1: 50$ & Raised by us (35) \\
\hline STC 1 & OTI6D12 & $1: 200$ & $\begin{array}{l}\text { OriGene } \\
\text { Technologies, Inc. }\end{array}$ \\
\hline Chromogranin A & PHE5 & $1: 100$ & $\begin{array}{l}\text { EMD Millipore } \\
\text { corporation }\end{array}$ \\
\hline MATH 1 & $\begin{array}{l}\text { Rabbit } \\
\text { polyclonal }\end{array}$ & $1: 100$ & $\begin{array}{l}\text { MBL International } \\
\text { Corporation }\end{array}$ \\
\hline CD56 & $\begin{array}{l}\text { Rabbit } \\
\text { polyclonal }\end{array}$ & $1: 200$ & Merck Millipore \\
\hline Synaptophysin & $27 G 12$ & $1: 100$ & Leica Biosystems \\
\hline INSM1 & $A-8$ & $1: 75$ & Nordic Biosite \\
\hline ISL1 & EP283 & $1: 50$ & Bio SB \\
\hline
\end{tabular}

\begin{tabular}{|c|c|}
\hline Product code & Positive signal \\
\hline Not available & $\begin{array}{l}\text { Nuclear and granular } \\
\text { sytoplasmic }\end{array}$ \\
\hline Not available & $\begin{array}{l}\text { Membranous and } \\
\text { cytoplasmic }\end{array}$ \\
\hline TA810025 & Granular cytoplasmic \\
\hline MAB319 & Granular cytoplasmic \\
\hline JM-3659-100 & Cytoplasmic \\
\hline AB5032 & Cytoplasmic \\
\hline NCL-SYNAP-299 & Cytoplasmic \\
\hline AZC-F34730 & Nuclear \\
\hline BSB2975 & Nuclear \\
\hline
\end{tabular}

\begin{tabular}{l} 
Controls \\
\hline Rabbit-negative \\
Mouse-negative \\
Mouse-negative \\
Mouse-negative \\
Rabbit-negative \\
Rabbit-negative \\
Mouse-negative \\
Pancreas-positive \\
Pancreas-positive
\end{tabular}




\section{Karyotype and multicolor FISH}

Cell culturing and metaphase-fluorescence in situ hybridization (FISH) preparations were performed according to standard cytogenetic procedures (20). Multicolor FISH karyotyping was performed with a 24XCYte mFISH probe kit (MetaSystems GmbH, Altslussheim, Germany). Hybridizations and post-hybridization washes were performed according to the manufacturers' instructions. A Zeiss Axioplan 2 Microscope equipped with specific filters was used. Captured images were processed using the Isis/Multicolor FISH imaging system (MetaSystems). Cells used in mFISH were from passage 16.

\section{Comparative genomic hybridization}

The DNA used for the CGH was isolated using a proteinase K-based method according to Behringer etal.(21). Proteinase K was obtained from Thermo Fisher Scientific Baltics UAB (V.A. Graiciuno 8, LT-02241, Vilnius, Lithuania). CGH was performed with tumor cell DNA isolated from passage 16 using the Cancer+SNP 43 180k micro-array (Oxford Gene Technology, Oxford, UK). Labeling, hybridization, scanning, and analysis were performed according to the manufacturers' instructions. Microarray slides were scanned using an Agilent DNA Microarray Scanner G2505 (Agilent Technologies Inc) and filtered with Feature Extraction software v12.0.07 (Agilent Technologies). Cytosure Software v4.9 (hg19) (Oxford Gene Technology) was used for graphic analysis of the data.

\section{qPCR method}

RNA was isolated from GNEN-1 cells with TRI REAGENT ${ }^{\circ}$ by Sigma-Aldrich according to the manufacturer's instructions from passage 12. cDNA was generated from RNA with the Applied Biosystems High Capacity RNA to cDNA Kit and it was used as a template for RT-PCR with gene-specific primers for STC1 and positive control GAPDH.

The primers used for STC1 were forward 5'-ACAGCAAGCTGAATGTGTGC-3' and reverse 5'-CAGGCTTCGGACAAGTCTGT-3'. The GAPDH primers used were forward 5'-GGTGAAGGTCGGAGTCAAC-3' and reverse 5'-CAAATGAGCCCCAGCCTTC-3'.

\section{RT-PCR}

RT-PCR was performed to investigate the presence of Merkel cell polyomavirus in the GNEN-1 cells. The DNA for the PCR was isolated from a passage 12 of the cell line as mentioned above. Protein tyrosine phosphatase receptor gamma (PTPRG, located on 3p14.2) and LT3 of MCPyV were used as reference and target genes, respectively. The primers used were PTPRG forward 5'-TATGGGAGTGTGGGATGGT-3' and reverse 5'-TAAGCTGGGAGGATCGCTTA-3' and LT3 forward 5'-TTGTCTCGCCAGCATTGTAG-3' and reverse 5'-ATATAGGGCCTCGTCAACC-3'. The PCR cycling conditions consisted of an initial denaturation step at $95^{\circ} \mathrm{C}$ for $4 \mathrm{~min}$, followed by 50 cycles with denaturation at $95^{\circ} \mathrm{C}$ for $30 \mathrm{~s}$, annealing at $60^{\circ} \mathrm{C}$ for $30 \mathrm{~s}$, and elongation at $72^{\circ} \mathrm{C}$ for $45 \mathrm{~s}$. The final elongation step was performed at $72^{\circ} \mathrm{C}$ for $7 \mathrm{~min}$. PCR was performed using a BioRad ${ }^{\circ} \mathrm{CFX}$ qPCR instrument. The virus positive control sample was from a Merkel cell carcinoma cell line MKL-1 (Cat. Nr. 09111801, ECACC). The negative control was water.

\section{Results}

\section{Cell line morphology and growth}

GNEN-1 cells grew as small cell islands in a monolayer (colonies). Upon extended culturing, the cells merged to confluence (Fig. 3). Single GNEN-1 cells frequently made dendrite-like sprouts. Immunocytochemically, the cells retained the NE differentiation; cytokeratin and chromogranin were positive (Fig. 3). Transmission electron microscopy revealed dense-core granules, GAP junctions, neurofilaments, and axon hillocks (Fig. 4). The kinetics of proliferation is shown in Fig. 2. GNEN-1 cells grew in a linear fashion, before reaching confluence. The duplication time for GNEN-1 cells was approximately 0.7 days and reached confluence in 3.5 days. The decrease in cells after day 4 represents cell death because of lack of growth surface. GNEN-1 cells grew as spheroids but did not invade semi-solid medium (Matrigel ${ }^{\circ}$ ) (data not shown).

\section{Karyotype of the GNEN-1 cell line}

M-FISH revealed several trisomies in the karyotype of the GNEN-1 cell line. The modal chromosomal number was approximately 52 . Recurrent translocations were $t(3 ; 8)$, $t(5 ; 19), t(6 ; 11)$, and $t(3 ; 11)$. The karyotype also revealed tris omies of chromosomes 1, 7, 8, 10, and 17 and deletion of chromosome 22.

\section{Comparative genomic hybridization (CGH) of the GNEN-1 cell line}

CGH performed with extracted DNA from the cell line revealed a chaotic structure of the chromosomes. The

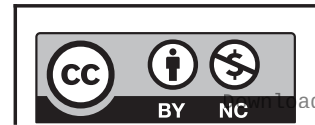

This work is licensed under a Creative Commons Attribution-NonCommercial 4.0 International License. ded from Bioscientifica.com at 04/26/2023 09:05:56AM via free access 

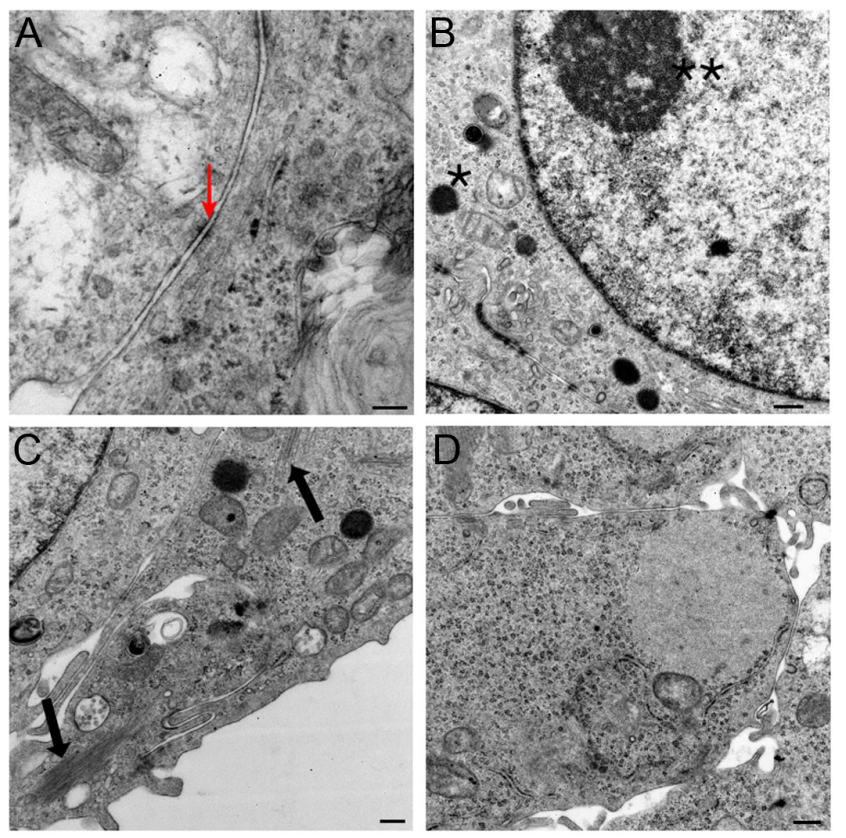

\section{Figure 3}

Transient electron microscopy (TEM) images of GNEN-1 cells. (A) Cell membranes of two cells showing GAP junctions (red arrow); scale bar represents $100 \mathrm{~nm}$. (B) Dense core granules (asterisk), which are typical for neuroendocrine cells. Nucleoli (double asterix) is clearly visible in this picture. (C) Neurofilaments (black arrow) and dense core granules are visible. (D) An axon hillock is seen in the image, supporting the neuroendocrine differentiation. In panels B, C, D the scale bar represents $200 \mathrm{~nm}$.

main findings were amplification of $8 \mathrm{q} 24.21$ where the MYC gene is located and amplification of $19 \mathrm{q} 12$, where the gene for Cyclin E1 (CCNE1) is located. There was also amplification on 3q28 containing the gene for tumor protein 63 (TP63) and loss in the loci of the tumor suppressor gene retinoblastoma 1 (RB1) (13q14.2). Loss of the loci containing the genes phosphatase and tensin homolog (PTEN) (10q23.31) was also observed.

\section{Immunohistochemistry of the cell line}

The GNEN-1 cell line stained positive for Synaptophysin and CD56, both are cytoplasmic granular staining, as shown in Fig. 5B and D. Nuclear staining was seen for ISL1 and INSM1 (Fig. 6).

\section{Stanniocalcin-1 in the GNEN-1 cell line}

Results from the qPCR performed on GNEN-1 cells revealed the presence of the following transcripts: GAPDH and STC1 in the same magnitude. GNEN-1 cells also stained positive for STC1 protein in immunohistochemistry (Fig. 7).

\section{NE-related markers in GNEN-1 cell line}

The GNEN-1 cells stained positively for AZIN2, REG4, and MATH1 (Fig. 7). AZIN2 staining was observed as small granules in the cytoplasm or in the nucleus. REG4 was positive mostly on the cell membrane and no nuclear positivity was observed. Expression of MATH1 was observed in the cytosol of GNEN-1 cells. The GNEN-1 cell line did not contain MCPyV-DNA when investigated by RT-PCR.

\section{Discussion}

Here we report a spontaneously immortalized continuous cell line called GNEN-1. GNEN-1 was established from a gastric mixed neuroendocrine-non-neuroendocrine (MINEN) tumor composed of adenocarcinoma and highgrade neuroendocrine carcinoma. We believe that this cell line will offer a tool for further research on MINEN tumors.

The in vitro morphology of the GNEN-1 cell line showed features of a neuroendocrine phenotype. Cells

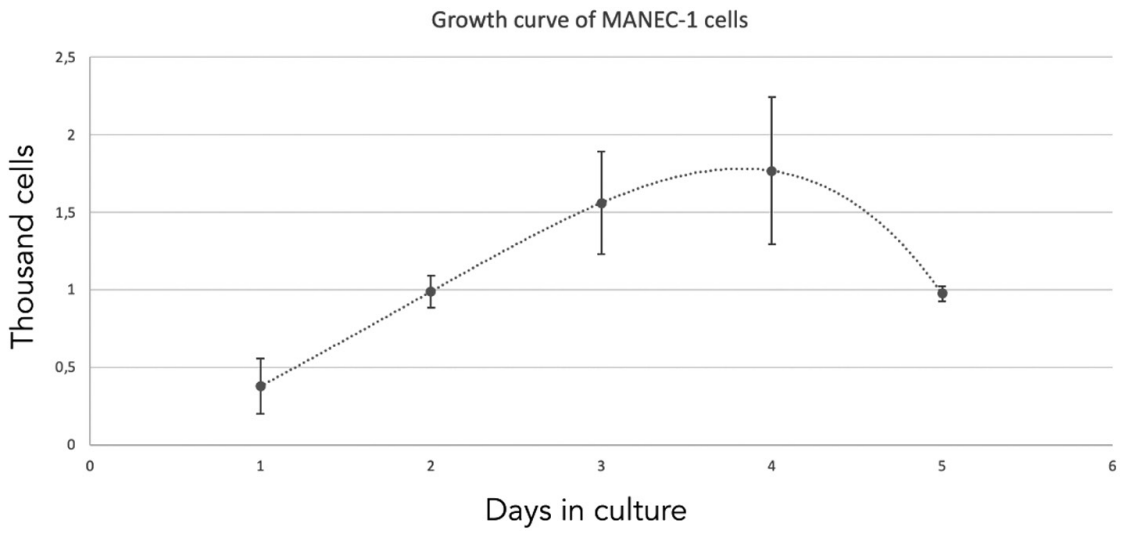

Figure 4

Growth curve of GNEN-1 cells growing in vitro. The GNEN-1 cells grow in a linear fashion before reaching confluence, in approximately 3-5 days. https://ec.bioscientifica.com https://doi.org/10.1530/EC-21-0206 (c) 2021 The authors Published by Bioscientifica Ltd

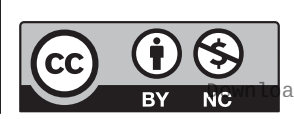

This work is licensed under a Creative Commons Attribution-NonCommercial 4.0 International License. ded from Bioscientifica.com at 04/26/2023 09:05:56AM via free access 

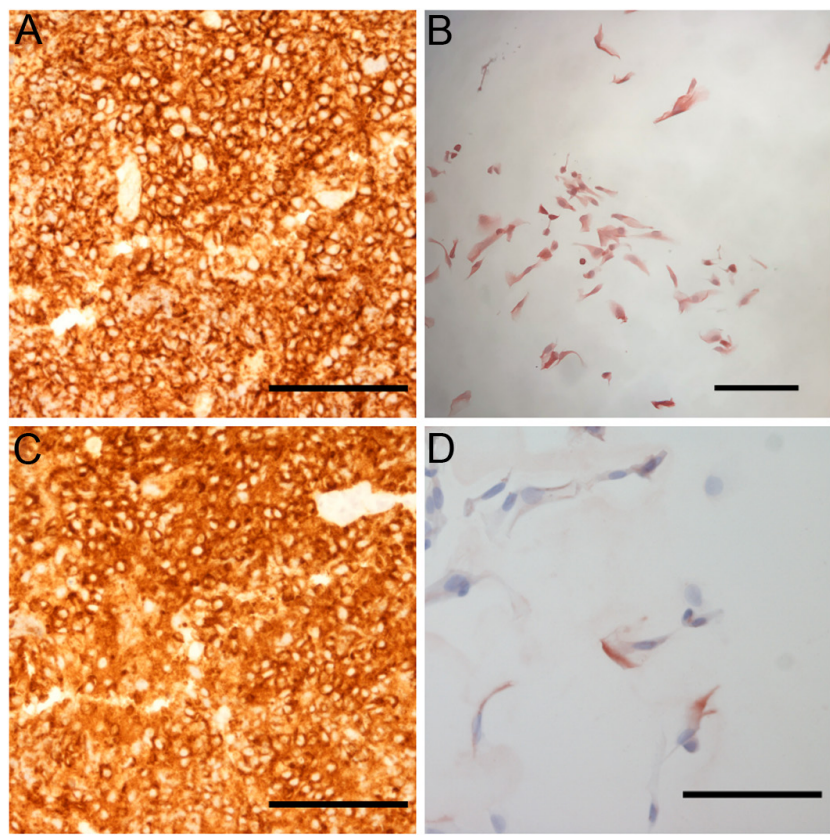

\section{Figure 5}

Immunohistochemistry of the NEC component of the primary tumor and GNEN-1 cells. (A) The NEC component of the primary tumor was stained with CD56. (B) GNEN-1 cells stained with CD56 diffusely in the cytoplasm. (C) The NEC component of the primary tumor stained with synaptophysin. (D) GNEN-1 cells stained with synaptophysin. The cells do not stain as evenly as with CD56, but clear cytoplasmic staining is seen. The scale bars represent $150 \mu \mathrm{m}$.

stained positive for chromogranin $\mathrm{A}$ and electron microscopy revealed dense core granules, neurofilaments, and axon hillocks. The liver metastases contained only the NEC component, indicating that the neuroendocrine component was more aggressive. This also explains the phenotype of the cell line, as it was established from metastatic peritoneal fluid cells. According to some studies, this pattern of metastasis is typical for these mixed neoplasms $(22,23,24)$.

The WHO criteria of MINEN state that both components should present at least $30 \%$ of the tumor volume. As the diagnosis of the primary tumor was performed on a biopsy, this kind of quantitative interpretation cannot be made in our case. However, at least two separate components, adenocarcinoma and highgrade neuroendocrine carcinoma, were identified thus supporting the diagnosis of MINEN. From the biopsy tissue at least $30 \%$ of it represented one of the components which supports a MINEN diagnosis but does not fully prove the MINEN diagnosis according to WHO. The GNEN-1 cell line did not represent the adenocarcinoma part of the primary tumor, suggesting that cells recovered from the ascites did not contain adenocarcinoma differentiation. Another
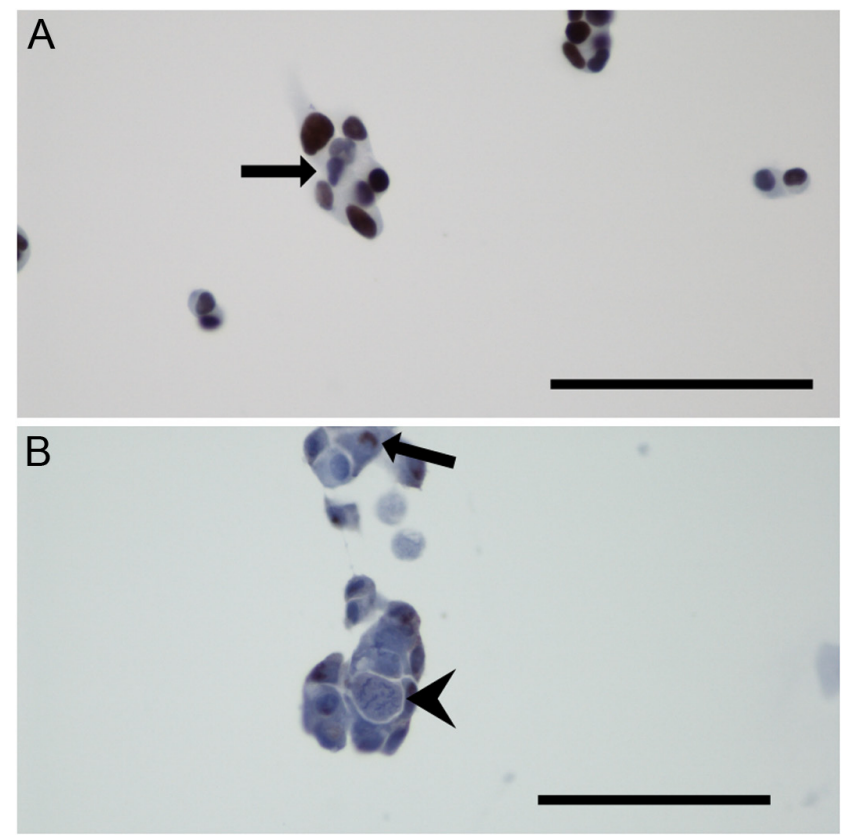

\section{Figure 6}

Automated immunohistochemistry with antibodies against (A) ISL1 with strong nuclear staining. Some of the nuclei are not stained (arrow). (B) INSM1 with some positivity in the nuclei (arrow). One of the cells is in anaphase (arrowhead). The scale bars represent $100 \mu \mathrm{m}$.
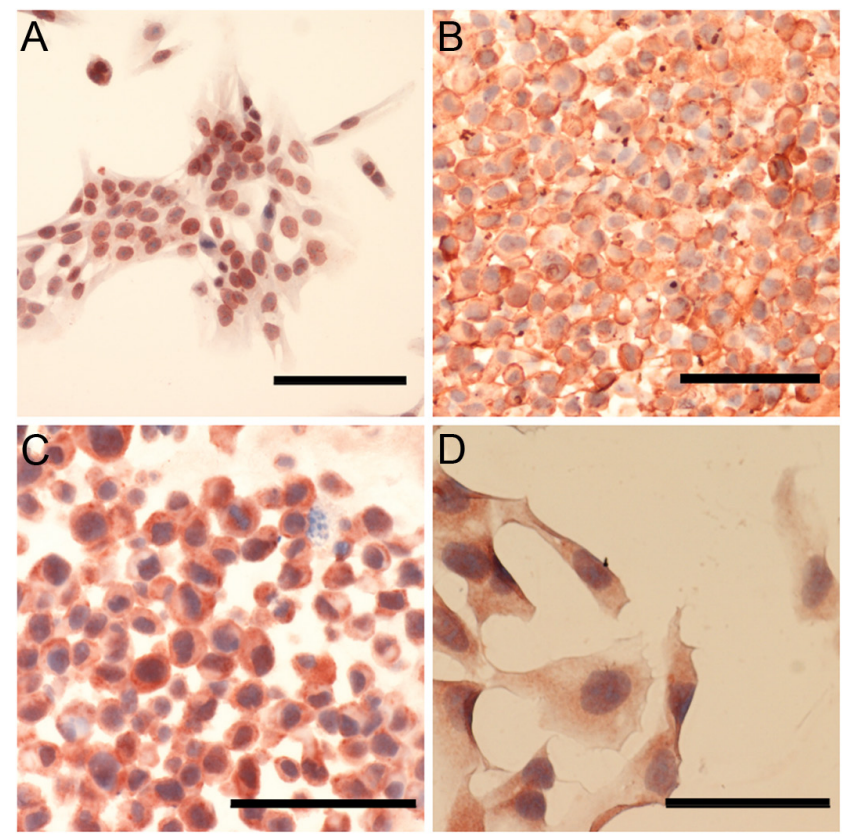

\section{Figure 7}

Immunohistochemistry of GNEN-1 cells against (A) AZIN2 where nuclear staining and some cytoplasmic granules are seen. (B) REG4 shows membranous staining with the lack of nuclear staining is seen. (C) MATH1 with cytoplasmic staining with lack of nuclear staining is seen. (D) STC1 with granular cytoplasmic and lack of nuclear staining. In panels A, B, C, the scale bar represents $100 \mu \mathrm{m}$ and in D $50 \mu \mathrm{m}$.

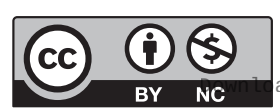

This work is licensed under a Creative Commons Attribution-NonCommercial 4.0 International License. ded from Bioscientifica.com at 04/26/2023 09:05:56AM 
explanation could be that two cell types are combined in vitro, the most viable cell clone will eventually take over.

The results from FISH showed trisomy of chromosomes 7 and 8 in GNEN-1 cells. Trisomies in these chromosomes have been reported to play a role in gastric adenocarcinoma tumorigenesis (25). This feature also suggests adenocarcinoma differentiation of the GNEN-1 cell line. A single trisomy of chromosome 7 has also been shown to occur in NEC derived from the breast (26).

Amplification of $19 \mathrm{q} 12$, which is found in many gastric adenocarcinomas (27), was also present in GNEN1. A gene in this locus codes for the CCNE1 protein (27), which contributes to the G1/S transition in the cell cycle. Overexpression of CCNE1 is found in many tumors (28). Gain in the TP63 gene was also observed in GNEN-1 cells. TP63 is connected to adult stem/progenitor cell regulation (29).

The genetic alterations (CGH and M-FISH) were similar in the primary tumor compared to the GNEN-1 cell line. This supports the hypothesis that the GNEN-1 cell line is derived from the primary tumor of the patient.

Even though there are cases of gastric NECs with identified MCPyV DNA, this was not found in GNEN-1 (1).

The pathogenesis of the MINEN tumor is poorly understood. It is believed that these tumors are derived from pluripotent stem cells and the neuroendocrine component is derived from the adenocarcinoma $(2,30$, 31). It is possible that inactivation of the SMARCA4 gene on chromosome 19 pushes the adenocarcinoma cells to differentiate toward NEC cells $(31,32)$. It has also been shown that MINEN has more chromosomal abnormalities in the NEC component than in the adenocarcinoma component (2), which further supports this hypothesis. Scardoni et al. (11) used microdissection to obtain exocrine and neuroendocrine cells from the same primary MINEN tumors. A comparison of the mutational profiles of the two components provided evidence for a monoclonal origin of the two cell types in five out of six tumors analyzed (11). Based on these observations, the possibilities are high that the GNEN-1 cell line is a true MINEN cell line, even though it has more features of NEC rather than adenocarcinoma.

Both the cell line and the NEC component of the primary tumor are stained positive with neuroendocrine correlated antibodies, both CD56 and synaptophysin (Fig. 5A, B, C and D). The cell line was also stained positive with the second-generation neuroendocrine markers (ISL1 and INSM1) as seen in Fig. 6, which further indicates the neuroendocrine phenotype of the cell line.
Expression of STC1 RNA in the GNEN-1 cells may explain in part the poor outcome of the patient. High STC1 expression indicates poor prognosis in gastric cancer. STC1 expression is also connected with chemoresistance and invasive growth in hypoxia (13).

AZIN2 is associated with intracellular vesicle transport and secretion (33), which then associate with the neuroendocrine nature of the cell line and the dense core granules seen in TEM. ATOH1 and REG4 are expressed in neuroendocrine tumors, which supports the neuroendocrine phenotype of the GNEN-1 cell line (15). All tree previously mentioned markers were positive in the IHC of the cell line as shown in Fig. 7.

The strength of this research is that it presents a new tool for research on gastric neuroendocrine neoplasias. To the best of our knowledge, this is the first report of a cell line derived from a gastric MINEN. Previous publications consist mostly of case reports and some larger studies of clinical factors. All biomedical research performed thus far has been on tumor tissue.

The limitation of this report is that the primary tumor could not be investigated fully, because of the lack of tumor tissue from the biopsies, and because of that the primary tumor or the metastasis was never surgically removed, as is often the case with mixed neuroendocrinenon-neuroendocrine tumors. MINEN tumors are often discovered at a disseminated stage of the disease and surgery is therefore not the treatment of choice.

In conclusion, we present a spontaneously immortalized cell line derived from an aggressive gastric MINEN tumor. In the future, the GNEN-1 cell line can be used as a tool to study pathogenesis of mixed gastric tumors in further detail. This cell line may also serve as a tool in the search for potential therapeutic targets.

\section{Declaration of interest}

The authors declare that there is no conflict of interest that could be perceived as prejudicing the impartiality of the research reported.

\section{Funding}

The author(s) disclosed receipt of the following financial support for the research, authorship, and/or publication of this article: The study was supported by The Sigrid Jusélius Foundation, The Magnus Ehrnrooth Foundation, Finska Läkaresällskapet, and Liv och Hälsa (WBS 4708047), Cancer Foundation Finland (WBS 4707973), Helsinki University hospital research fund (TYH2019205), Jane and Aatos Erkko Foundation.

\section{Ethical statement}

The research was approved by an independent ethical committee of Helsinki University Hospital (1258/2020). Patient consent was obtained for the GNEN-1 cell line.

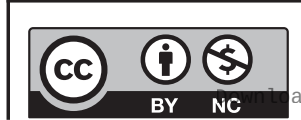

This work is licensed under a Creative Commons Attribution-NonCommercial 4.0 International License. ded from Bioscientifica,com at 04/26/2023 09:05:56 AM via free access 


\section{Author contribution statement}

K W Fagerstedt has been the main writer and researcher of the work, and text. T Böhling has been one of the supervisors of the project. $H$ Sihto is has been designing the PCR part of the work. T Salonen has designed and done the genetical laboratory work. F Zhao has done the TEM imaging and the analysis of the images. M Kero has designing the fully automated IHCprotocols. L C Andersson established the cell line and has been the one of main supervisor of the laboratory work, and with Fagerstedt the main designer of the project. J Arola has been one of the main supervisors of the project and the supervisor of the writing project. All of the authors have given the final approval of the research to be published.

\section{Acknowledgements}

We thank Ms Tiiu Aurmäe for excellent technical assistance. We thank the patient for the permission to establish the cell line.

\section{References}

1 La Rosa S, Rindi G, Solcia E, Tang LH \& WHO Classification of Tumors Editorial Board. Gastric neuroendocrine neoplasms. In Digestive System Tumors, 5th ed., pp. 104-109. Eds F Carneiro, JKC Chan, N-YA Cheung, IA Cree, PL Fitzgibbons, S Gasson, et al. Lyon, F rance: International Agency for Research on Cancer, 2019.

2 La Rosa S, Marando A, Sessa F \& Capella C. Mixed adenoneuroendocrine carcinomas (MANECs) of the gastrointestinal tract: an update. Cancers 20124 11-30. (https://doi.org/10.3390/ cancers4010011)

3 Komo T, Kohashi T, Nakashima A, Ohmori I, Hihara J, Mukaida H, Kaneko M \& Hirabayashi N. Mixed adenoneuroendocrine carcinoma of the distal bile duct: a case report. International Journal of Surgery Case Reports 201739 203-207. (https://doi.org/10.1016/j.ijscr.2017.08.031)

4 Eckstein M, Rasper B, Busche J, Stachetzki U, Wistuba D, Agaimy A, Hartmann A \& Bertz S. Primäres gemischtes adeno-neuroendokrines Karzinom (MANEC) der Harnblase - eine seltene Entität. Aktuelle Urologie 201748 350-355. (https://doi.org/10.1055/s-0043-110088)

5 Millione M, Maissonneuve P, Pellegrinelli A, Grillo F, Albarello L, Spaggiari P, Vanoli A, Tagliabue G, Pisa E, Messerini L, et al. Ki67 proliferative index of the neuroendocrine component drives MANEC prognosis. Endocrine-Related Cancer 201825 583-593. (https://doi. org/10.1530/ERC-17-0557)

6 Brathwaite S, Yearsley MM, Bekaii-Saab T, Wei L, Schmidt CR, Dillhoff ME, Frankel WL, Hays JL, Wu C \& Abdel-Misih S. Appendiceal mixed adeno-neuroendocrine carcinoma: a population-based study of the surveillance, epidemiology, and end results registry. Frontiers in Oncology 20166 148. (https://doi.org/10.3389/fonc.2016.00148)

7 Pham QD, Mori I \& Osamura RY. A case report: gastric mixed neuroendocrine-nonneuroendocrine neoplasm with aggressive neuroendocrine component. Case Reports in Pathology 20172017 9871687. (https://doi.org/10.1155/2017/9871687)

8 Furlan D, Cerutti R, Genasetti A, Pelosi G, Uccella S, La Rosa S $\&$ Capella C. Microallelotyping defines the monoclonal or the polyclonal origin of mixed and collision endocrine-exocrine tumors of the gut. Laboratory Investigation 200383 963-971. (https://doi. org/10.1097/01.lab.0000079006.91414.be)

9 Kim B, Yang HK \& Kim WH. Multiple neuroendocrine tumors in stomach and duodenum in a multiple endocrine neoplasia type 1 patient. Journal of Pathology and Translational Medicine 201852 126-129. (https://doi.org/10.4132/jptm.2017.09.16)

10 Volante M, Monica V, Birocco N, Brizzi MP, Busso S, Daniele L, La Rosa S, Righi L, Sapino A, Berruti A, et al. Expression analysis of genes involved in DNA repair or synthesis in mixed neuroendocrine/ nonneuroendocrine carcinomas. Neuroendocrinology 2015101 151-160. (https://doi.org/10.1159/000375449)
11 Scardoni M, Vittoria E, Volante M, Rusev B, Bersani S, Mafficini A, Gottardi M, Giandomenico V, Malleo G, Butturini G, et al. Mixed adenoneuroendocrine carcinomas of the gastrointestinal tract: targeted next-generation sequencing suggests a monoclonal origin of the two components. Neuroendocrinology $2014100310-316$. (https:// doi.org/10.1159/000369071)

12 Zhang Kz, Lindsberg PJ, Tatlisumak T, Kaste M, Olsen HS \& Andersson LC. Stanniocalcin: a molecular guard of neurons during cerebral ischemia. PNAS 200097 3637-3642. (https://doi.org/10.1073/ pnas.070045897)

13 Wang Y, Qi Z, Zhou M, Yang W, Hu R, Li G, Ma X \& Zhang Z Stanniocalcin-1 promotes cell proliferation, chemoresistance and metastasis in hypoxic gastric cancer cells via $\mathrm{Bcl} 2$. Oncology Reports 201941 1998-2008. (https://doi.org/10.3892/or.2019.6980)

14 Mäkitie L, Andersson LC, Carpen O, Eloranta T \& Halmekytö M. The Functions and Regulation of Ornithine Decarboxylase, 53 pp. Yliopistopaino, 2010.

15 Heiskala K, Arola J, Heiskala M \& Andersson LC. Expression of Reg IV and Hath1 in neuroendocrine neoplasms. Histology and Histopathology 201025 63-72. (https://doi.org/10.14670/HH-25.63)

16 Mukhopadhyay S, Dermawan JK, Lanigan CP \& Farver CF. Insulinomaassociated protein 1 (INSM1) is a sensitive and highly specific marker of neuroendocrine differentiation in primary lung neoplasms: an immunohistochemical study of 345 cases, including 292 whole-tissue sections. Modern Pathology 201932 100-109. (https://doi.org/10.1038/ s41379-018-0122-7)

17 Gierl MS, Karoulias N, Wende H, Strehle M \& Birchmeier C. The zinc-finger factor Insm1 (IA-1) is essential for the development of pancreatic $\beta$ cells and intestinal endocrine cells. Genes and Development 200620 2465-2478. (https://doi.org/10.1101/gad.381806)

18 Lee H, Fu Z, Koo BH, Sheehan CE, Young GQ, Lin J, Patil DT \& Yang Z. The expression of TTF1, CDX2 and ISL1 in 74 poorly differentiated neuroendocrine carcinomas. Annals of Diagnostic Pathology 201837 30-34. (https://doi.org/10.1016/j.anndiagpath.2018.09.005)

19 Wang W, Shi Q, Guo T, Yang Z, Jia Z, Chen P \& Zhuo C. PDX1 and ISL1 differentially coordinate with epigenetic modifications to regulate insulin gene expression in varied glucose concentrations. Molecular and Cellular Endocrinology 2016428 38-48. (https://doi.org/10.1016/j. mce.2016.03.019)

20 Howe B, Umrigar A \& Tsien F. Chromosome preparation from cultured cells. Journal of Visualized Experiments 201483 e50203. (https://doi. org/10.3791/50203)

21 Behringer R, Gertsenstein M, Nagy KV \& Nagy A. Isolation of highmolecular-weight DNA from mouse tail tips. Cold Spring Harbor Protocols 20192019 pdb.prot092692. (https://doi.org/10.1101/pdb. prot092692)

22 Tang Q, Zhou Z, Chen J, Di M, Ji J, Yuan W, Liu Z, Wu L, Zhang X, Li K, et al. Correlation of metastasis characteristics with prognosis in gastric mixed adenoneuroendocrine carcinoma: two case reports. Medicine 201796 e9189. (https://doi.org/10.1097/MD.0000000000009189)

23 Zhang W, Xiao W, Ma H, Sun M, Chen H \& Zheng S. Neuroendocrine liver metastasis in gastric mixed adenoneuroendocrine carcinoma with trilineage cell differentiation: a case report. International Journal of Clinical and Experimental Pathology 20147 6333-6338.

24 Chen H, Shu M, Chen S, Xue L \& Lin Y. Clinicopathological features and lymph node metastatic patterns of gastric mixed adenoneuroendocrine carcinoma. Histology and Histopathology 2019 34 373-379. (https://doi.org/10.14670/HH-18-045)

25 Leal MF, Martins do Nascimento JL, Da Silva CEA, Vita Lamarão MF, Calcagno DQ, Khayat AS, Assumpção P, Cabral I, de Arruda Cardoso Smith M \& Burbano R. Establishment and conventional cytogenetic characterization of three gastric cancer cell lines. Cancer Genetics and Cytogenetics 2009195 85-91. (https://doi.org/10.1016/j. cancergencyto.2009.04.020)

26 Xiang DB, Wei B, Abraham SC, Huo L, Albarracin CT, Zhang H, Babiera G, Caudle AS, Akay CL, Rao P, et al. Molecular cytogenetic characterization https://ec.bioscientifica.com https://doi.org/10.1530/EC-21-0206 (c) 2021 The authors Published by Bioscientifica Lto
This work is licensed under a Creative Commons Attribution-NonCommercial 4.0 International License. ded from Bioscientifica.com at 04/26/2023 09:05:56AM 
of mammary neuroendocrine carcinoma. Human Pathology 201445 1951-1956. (https://doi.org/10.1016/j.humpath.2014.06.002)

27 Leung SY, Ho C, Tu IP, Li R, So S, Chu KM, Yuen ST \& Chen X. Comprehensive analysis of $19 \mathrm{q} 12$ amplicon in human gastric cancers. Modern Pathology 200619 854-863. (https://doi.org/10.1038/ modpathol.3800593)

28 Kim B, Shin HC, Heo YJ, Ha SY, Jang KT, Kim ST, Kang WK, Lee J \& Kim KM. CCNE1 amplification is associated with liver metastasis in gastric carcinoma. Pathology, Research and Practice 2019215152434. (https://doi.org/10.1016/j.prp.2019.152434)

29 Nekulova M, Holcakova J, Coates P \& Vojtesek B. The role of P63 in cancer, stem cells and cancer stem cells (Internet). Cellular and Molecular Biology Letters 201116 296-327. (https://doi.org/10.2478/ s11658-011-0009-9)

30 Xie JW, Lu J, Wang JB, Lin JX, Chen QY, Cao LL, Lin M, Tu RH, Huang ZN, Lin JL, et al. Prognostic factors for survival after curative resection of gastric mixed adenoneuroendocrine carcinoma: a series of 80 patients. BMC Cancer 201818 1021. (https://doi.org/10.1186/ s12885-018-4943-z)

31 Vanacker L, Smeets D, Hoorens A, Teugels E, Algaba R, Dehou MF, DeBecker A, Lambrechts D \& De Greve J. Mixed adenoneuroendocrine carcinoma of the colon: molecular pathogenesis and treatment. Anticancer Research 201434 5517-5521.

32 Agaimy A, Fuchs F, Moskalev EA, Sirbu H, Hartmann A \& Haller F. SMARCA4-deficient pulmonary adenocarcinoma: clinicopathological, immunohistochemical, and molecular characteristics of a novel aggressive neoplasm with a consistent TTF1neg/CK7pos/HepPar-1pos immunophenotype. Virchows Archiv 2017471 599-609. (https://doi. org/10.1007/s00428-017-2148-5)

33 Kaprio T, Rasila T, Hagström J, Mustonen H, Lankila P, Haglund C \& Andersson LC. Ornithine decarboxylase antizyme inhibitor 2 (AZIN2) is a signature of secretory phenotype and independent predictor of adverse prognosis in colorectal cancer. PLoS ONE 201914 e0211564. (https://doi.org/10.1371/journal.pone.0211564)

34 Rasila T, Lehtonen A, Kanerva K, Mäkitie LT, Haglund C \& Andersson LC. Expression of ODC antizyme inhibitor 2 (AZIN2) in human secretory cells and tissues. PLoS ONE 201611 e0151175. (https://doi.org/10.1371/journal.pone.0151175)

35 Heiskala K, Giles-Komar J, Heiskala M \& Andersson LC. High expression of RELP (Reg IV) in neoplastic goblet cells of appendiceal mucinous cystadenoma and pseudomyxoma peritonei. Virchows Archiv 2006448 295-300. (https://doi.org/10.1007/s00428-005-0105-1)

Received in final form 2 August 2021

Accepted 4 August 2021

Accepted Manuscript published online 4 August 2021
This work is licensed under a Creative Commons Attribution-NonCommercial 4.0 International License. ded from Bioscientifica.com at 04/26/2023 09:05:56 AM via free access 